\title{
Lichens of fruit trees in the selected locations in Podlaskie Voivodeship [North-Eastern Poland]
}

\author{
Porosty drzew owocowych w wybranych miejscach \\ województwie podlaskim [Polska Północno-Wschodnia]
}

\author{
${ }^{*}$ Dr Anna Matwiejuk - University of Bialystok, Institute of Biology, Department \\ of Plant Ecology, Konstanty Ciołkowski $1 \mathrm{~J}$ street, PL-15-245 Bialystok; \\ email: matwiej@uwb.edu.pl
}

Keywords: lichenized fungi, epiphytes, species diversity, occurrence, fruit orchards, Podlaskie Voivodeship, North-Eastern Poland Słowa kluczowe: grzyby zlichenizowane, epifity, różnorodność gatunkowa, występowanie, sady owocowe, województwo podlaskie, Polska Północno-Wschodnia

\begin{abstract}
The aim of this paper is to present the diversity of the lichen species on fruit trees (Malus sp., Pyrus sp., Prunus sp. and Cerasus sp.) growing in orchards in selected villages and towns in the Podlaskie Voivodeship. Fifty-six species of lichens were found. These were dominated by common lichens found on the bark of trees growing in built-up areas with prevailing heliophilous and nitrophilous species of the genera Physcia and Phaeophyscia. A richer lichen biota is characteristic of apple trees (52 species) and pear trees (36). Lichens of the apple trees constitute $78 \%$ of the biota of this phorophyte growing in the fruit orchards in Poland. Of the recorded species, only two (Ramalina farinacea, Usnea hirta) are covered by partial protection in Poland.
\end{abstract}

๑) IOŚ-PIB

\section{INTRODUCTION}

Fruit orchards, as agricultural lands, are a constant element of the agricultural landscape of Poland. They are the place of occurrence of many species of plants and animals, mainly birds and insects, as well as lichens, fungi and mosses that colonise the bark of fruit trees. Establishing of fruit orchards is an example of human activity, which leads to the increase in the coverage of some species of lichens. Their presence in the agricultural landscape clearly enhances the mosaic and heterogeneity of the natural environment.

Research on fruit tree lichens was discussed in several papers, for example, by Kuziel [1964a, b], Kiszka and Piórecki [1991], Kościelniak [1998, 2004], Lipnicki and Sobieralska [2009], Zarabska et al. [2009], Zarabska [2011], Łubek and Biskup [2012]. The studies on lichen biota in different areas usually mention only single species of lichens from individual fruit trees, often growing at the periphery of forests or in built-up areas [Wilkoń-Michalska et al. 1988, Kiszka, Piórecki 1994, Kościelniak 2004, Łubek 2007, Szczepańska 2008, Matwiejuk, Korobkiewicz 2012 and others]. The data concerning lichens of fruit trees in north-eastern Poland, including the Podlaskie Voivodeship, are largely incomplete. They mostly come from the individually growing fruit trees, for

\section{Streszczenie}

Głównym celem pracy było przedstawienie zróżnicowania składu gatunkowego porostów występujących na korze drzew owocowych (Malus sp., Pyrus sp., Prunus sp. i Cerasus sp.) rosnących $w$ sadach $w$ wybranych miejscowościach w województwie podlaskim. Stwierdzono 56 gatunków porostów. Odnotowane gatunki to w większości porosty pospolite, notowane na korze drzew rosnących na terenach zabudowanych. Dominują gatunki światłolubne, pyłolubne i nitrofilne z rodzaju Physcia, Phaeophyscia, Polycauliona, Xanthoria. Najbogatszą biotą porostów charakteryzują się jabłonie (52 gatunki) i grusze (36). Porosty jabłoni badanego terenu stanowią $78 \%$ bioty tego forofitu, rosnących w sadach owocowych w Polsce. Spośród odnotowanych gatunków tylko dwa (Ramalina farinacea, Usnea hirta) objęte są ochroną częściową w Polsce.

example, from the Wigry National Park [Fałtynowicz 1994], from Białystok region [Matwiejuk 2007] or the Warmia Plain [Szymczyk, Zalewska 2008].

The subject of this study are lichens growing on the bark of the following fruit trees: Malus sp., Pyrus sp., Prunus sp. and Cerasus $\mathrm{sp}$. in the cultivated fruit orchards.

The main objective of this study is to present the diversity of lichen species of fruit trees growing in the orchards of the Podlaskie Voivodeship. So far, no similar lichenological work has been carried out in this region.

\section{STUDY AREA}

The study area embraces selected villages located in seven municipalities (Białystok, Janów, Krynki, Michałowo, Narewka, Zabludów and Zambrów) in the Podlaskie Voivodeship. The study area belongs to several mezoregions, including: Bialystok Upland, Wysokomazowiecka Upland, Sokólskie Hills, Bielsk Plain and Upper Narew Valley, which are parts of the macroregion of the North Podlasie Plain [Kondracki 2002]. 


\section{METHODS AND MATERIAL}

The field research was conducted in 10 stands, in the years 20152016 (Fig 1). A group of trees in old fruit orchards was accepted as an individual stand. From each stand, lichens were recorded from the bark of fruit trees up to $1.6 \mathrm{~m}$. The geographical coordinates of the study sites in the Podlaskie Voivodeship were established using GPS. GPS coordinates used the WGS84 datum.

List of research stands:

1. Ryboły [52 $\left.55^{\prime} 57^{\prime \prime N} 23^{\circ} 15^{\prime} 49^{\prime \prime} \mathrm{E}\right]$, Cerasus sp. Malus sp., Pyrus sp.

2. Krynki $\left[53^{\circ} 15^{\prime} 55^{\prime \prime N} 23^{\circ} 46^{\prime} 20^{\prime \prime} \mathrm{E}\right]$, Cerasus sp., Malus sp., Pyrus sp.

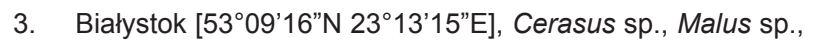
Pyrus sp., Prunus sp.

4. Stary Laskowiec $\left[52^{\circ} 56^{\prime} 39^{\prime \prime} \mathrm{N} 22^{\circ} 18^{\prime} 28^{\prime \prime} \mathrm{E}\right]$, Malus sp., Prunus sp.

5. Nowy Laskowiec $\left[52^{\circ} 56^{\prime} 39^{\prime \prime} \mathrm{N} 22^{\circ} 18^{\prime} 29^{\prime \prime} \mathrm{E}\right]$, Malus sp., Prunus sp.

6. Wdziękoń Pierwszy [52 $\left.57^{\prime} 47^{\prime \prime N} 22^{\circ} 18^{\prime} 51^{\prime \prime E}\right]$, Malus sp., Prunus sp.

7. Wasilówka [532 $\left.27^{\prime} 43^{\prime \prime} \mathrm{N} 23^{\circ} 16^{\prime} 31^{\prime \prime E}\right]$, Malus sp., Prunus sp., Pyrus sp.

8. Studzieńczyna $\left[53^{\circ} 27^{\prime} 41^{\prime \prime} \mathrm{N} 23^{\circ} 18^{\prime \prime E}\right]$, Malus sp.

9. Narewka [52 $\left.50^{\prime} 10^{\prime \prime} \mathrm{N} 23^{\circ} 45^{\prime} 27^{\prime \prime} \mathrm{E}\right]$, Malus sp., Pyrus sp.

10. Pieńki $\left[53^{\circ} 03^{\prime} 18^{\prime \prime N} 23^{\circ} 37^{\prime} 25^{\prime \prime E}\right]$, Malus sp., Prunus sp., Pyrus sp.

The lists of species of lichenized fungi at individual sites were made. Herbarium material was collected for lichenological documentation and identification of some taxa. Specimens were studied morphologically and anatomically by microscopy. The material collected was determined using lichen identification keys by Nowak and Tobolewski [1975], Wirth [1980, 1995] and Purvis et al. [1992]. The specimens of genus Lepraria, Cladonia pyxidata-chlorophaea group and Lecanora expallens were determined by TLC in solvent systems A and C [Orange et al. 2003]. The lichen species nomenclature followed Faltynowicz, Kossowska [2016]. Specimens were stored in the Herbarium of the Institute of Biology of the University of Bialystok.

\section{RESULTS}

In the fruit orchards in the Podlaskie Voivodeship, 56 species of lichens were found. Most of the species are representatives of the genus Lecanora (10 species), Physcia (5), Cladonia and Lepraria (such as 3).

The number of identified taxa varied from 10 (in stand 8) to 34 (in stand 3). In all the studied orchards, Candelariella xanthostigma, Hypogymnia physodes, Physcia dubia, P. tenella, Polycauliona polycarpa and Xanthoria parietina were recorded. Cladonia chlorophaea, Lecania cyrtella, Lecanora allophana, L. symmicta and $L$. varia have individual sites.

The highest number of lichen species was found on bark of Malus sp. -52 species and Pyrus sp. -36 species.

Amandinea punctata, Candelaria concolor, Candelariella xanthostigma, Hypogymnia physodes, Lecanora carpinea,

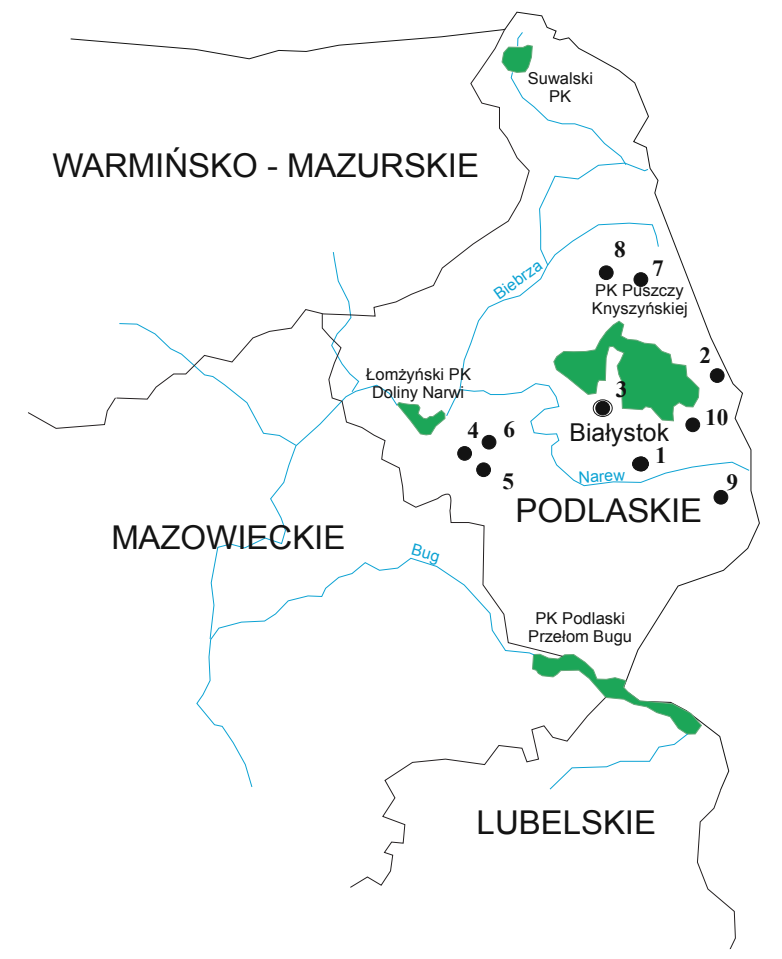

Figure 1. Locations of investigation sites of lichen species of fruit trees in Podlaskie Voivodeship.

Lepraria incana, Melanohalea exasperatula, Phaeophyscia orbicularis, Physcia adscendens, P. tenella, Polycauliona polycarpa and Xanthoria parietina were often recorded, among others, on the bark of Malus sp. Malus sp. is characterized by the largest number of exclusive species. Among them are: Caloplaca cerina, Cladonia coniocraea, Lecania cyrtella, Lecanora allophana, L. saligna, Micarea denigrata, Physcia aipolia, Ramalina farinacea and Usnea subfloridana. Lichen thalli were found on the bark of this phorophyte throughout the height of the tree, mostly in the middle of the trunk and in the crown. Almost all the morphological forms can be distinguished among them, although crustose and foliose lichens dominate. Numerous genera of Lecanora, Physcia and Phaeophysia are represented. The bark of Pyrus sp., similar to the bark of Malus sp., is dominated by the lichens of genus: Hypogymnia, Lecanora, Physcia, Phaeophyscia and Xanthoria. There are no exclusive species found on Pyrus sp.

A smaller number of lichen species was found on the bark of Prunus sp. and Cerasus sp. (30 species). Rinodina pyrina is an exclusive species for Prunus sp. and Hypocenomyce scalaris is exclusive for Cerasus sp. (Tab. 1).

From among the epiphytes growing on the bark of fruit trees, two species (Ramalina farinacea and Usnea hirta) are legally protected [Regulation of the Minister of the Environment 2014]. Six species have been put on the Red list of lichens in Poland [Cieśliński et al. 2006], including Melanelixa subargentifera, Ramalina farinacea, Usnea hirta in the vulnerable category - VU, Evernia prunastri, Hypogymnia tubulosa in the category of near threatened - NT and Strangospora pinicola in the category of least concern (LC). 
Table 1. The list of lichen species found in fruit orchards at different sites in Podlaskie Voivodeship.

\begin{tabular}{|c|c|c|}
\hline Species & Stands & Substrate \\
\hline Amandinea punctata (Hoffm.) Coppins \& Scheid. & $1-6,9,10$ & $\mathrm{Ce}, \mathrm{Ma}, \mathrm{Pr}, \mathrm{Py}$ \\
\hline Athalia pyracea (Ach.) Arup, Frödèn \& Søchting & $1,3,9$ & $\mathrm{Ce}, \mathrm{Ma}, \mathrm{Pr}, \mathrm{Py}$ \\
\hline Buellia griseovirens (Turner \& Borrer ex Sm.) Almb. & 2,3 & $\mathrm{Ce}, \mathrm{Ma}, \mathrm{Pr}, \mathrm{Py}$ \\
\hline Caloplaca cerina (Ehrh. ex Hedw.) Th. Fr. & 1,3 & $\mathrm{Ma}$ \\
\hline Candelaria concolor (Dicks.) Stein & $1-6,9,10$ & $\mathrm{Ce}, \mathrm{Ma}, \mathrm{Pr}, \mathrm{Py}$ \\
\hline Candelariella xanthostigma (Ach.) Lettau & $1-10$ & $\mathrm{Ce}, \mathrm{Ma}, \mathrm{Pr}, \mathrm{Py}$ \\
\hline Cladonia chlorophaea (Flörke ex Sommerf.) Spreng & 1 & $\mathrm{Ma}, \mathrm{Py}$ \\
\hline Cladonia coniocraea auct. & 1,10 & $\mathrm{Ma}$ \\
\hline Cladonia fimbriata (L.) Fr. & $1,2,3$ & $\mathrm{Ce}, \mathrm{Py}$ \\
\hline Evernia prunastri (L.) Ach. & $1-3,9,10$ & $\mathrm{Ce}, \mathrm{Ma}, \mathrm{Pr}, \mathrm{Py}$ \\
\hline Hypocenomyce scalaris (Ach.) Choisy & 3,7 & $\mathrm{Ce}$ \\
\hline Hypogymnia physodes (L.) Nyl. & $1,2-10$ & $\mathrm{Ce}, \mathrm{Ma}, \mathrm{Pr}, \mathrm{Py}$ \\
\hline Hypogymnia tubulosa (Schaer.) Hav. & $1,3,9,10$ & $\mathrm{Ma}, \mathrm{Py}$ \\
\hline Lecania cyrtella (Ach.) Th. Fr. & 3 & $\mathrm{Ma}$ \\
\hline Lecanora allophana (Ach.) Nyl. & 1 & $\mathrm{Ma}$ \\
\hline Lecanora argentata (Ach.) Malme & 2,9 & $\mathrm{Ma}$ \\
\hline Lecanora carpinea (L.) Vain. & $1-3,5,6,10$ & $\mathrm{Ce}, \mathrm{Ma}, \mathrm{Pr}, \mathrm{Py}$ \\
\hline Lecanora chlarotera Nyl. & 1,3 & $\mathrm{Ce}, \mathrm{Ma}, \mathrm{Pr}, \mathrm{Py}$ \\
\hline Lecanora conizaeoides Nyl. & $1-4,9,10$ & $\mathrm{Ce}, \mathrm{Ma}, \mathrm{Pr}, \mathrm{Py}$ \\
\hline Lecanora expallens Ach. & $1,3,9$ & $\mathrm{Ce}, \mathrm{Ma}, \mathrm{Pr}, \mathrm{Py}$ \\
\hline Lecanora pulicaris (Pers.) Ach. & $1-3,9$ & $\mathrm{Ce}, \mathrm{Ma}, \mathrm{Pr}, \mathrm{Py}$ \\
\hline Lecanora saligna (Schrad.) Zahlbr. & 1,9 & $\mathrm{Ma}$ \\
\hline Lecanora symmicta (Ach.) Ach. & 3 & $\mathrm{Ce}, \mathrm{Ma}, \mathrm{Pr}, \mathrm{Py}$ \\
\hline Lecanora varia (Hoffm.) Ach. & 3 & $\mathrm{Ma}$ \\
\hline Lecidella elaeochroma (Ach.) Choisy & $1,9,10$ & $\operatorname{Pr}, \mathrm{Py}$ \\
\hline Lepraria elobata Tønsberg & 6,9 & $\mathrm{Ma}$ \\
\hline Lepraria incana (L.) Ach. & 3,4 & $\mathrm{Ce}, \mathrm{Ma}, \mathrm{Pr}, \mathrm{Py}$ \\
\hline Lepraria jackii Tønsberg & 5,10 & $\mathrm{Ma}$ \\
\hline Melanelixia glabratula (Lamy) O. Blanco \& al. & $1-7,10$ & $\mathrm{Ce}, \mathrm{Ma}, \mathrm{Pr}, \mathrm{Py}$ \\
\hline Melanelixia subargentifera (Nyl.) O. Blanco \& al. & 3,9 & $\mathrm{Ce}, \mathrm{Ma}, \mathrm{Pr}, \mathrm{Py}$ \\
\hline Melanohalea exasperatula (Nyl.) O. Blanco \& al. & $1,2,4-10$ & $\mathrm{Ma}, \mathrm{Pr}, \mathrm{Py}$ \\
\hline Micarea denigrata (Fr.) Hedl. & 9 & $\mathrm{Ma}$ \\
\hline Myriolecis hagenii (Ach.) Śliwa, Zhao Xin \& Lumbsch & $1-6,9$ & $\mathrm{Ce}, \mathrm{Ma}, \mathrm{Pr}, \mathrm{Py}$ \\
\hline Parmelia sulcata Taylor & $1-10$ & $\mathrm{Ce}, \mathrm{Ma}, \mathrm{Pr}, \mathrm{Py}$ \\
\hline Parmeliopsis ambigua (Wulfen) Nyl. & 3 & $\mathrm{Ce}, \mathrm{Ma}, \mathrm{Pr}, \mathrm{Py}$ \\
\hline Pertusaria coccodes (Ach.) Nyl. & $5,7,8$ & $\mathrm{Ma}$ \\
\hline Phaeophyscia nigricans (Flörke) Moberg & $4,5,6$ & $\mathrm{Ma}, \mathrm{Pr}$ \\
\hline Phaeophyscia orbicularis (Neck.) Moberg & $1-7,9,10$ & $\mathrm{Ce}, \mathrm{Ma}, \mathrm{Pr}, \mathrm{Py}$ \\
\hline Phlyctis argena (Ach.) Flot. & 3 & $\mathrm{Ce}, \mathrm{Ma}, \mathrm{Pr}, \mathrm{Py}$ \\
\hline Physcia adscendens (Fr.) H. Olivier & $1-6,9,10$ & $\mathrm{Ce}, \mathrm{Ma}, \mathrm{Pr}, \mathrm{Py}$ \\
\hline Physcia aipolia (Ehrh. ex Humb.) Fürnrohr subsp. aipolia & 9 & $\mathrm{Ma}$ \\
\hline Physcia dubia (Hoffm.) Lettau & $1-10$ & $\mathrm{Ce}, \mathrm{Ma}, \mathrm{Pr}, \mathrm{Py}$ \\
\hline Physcia stellaris (L.) Nyl. subsp. Stellaris & $1-3,6,9,10$ & $\mathrm{Ce}, \mathrm{Ma}, \mathrm{Pr}, \mathrm{Py}$ \\
\hline Physcia tenella (Scop.) DC. & $1-10$ & $\mathrm{Ce}, \mathrm{Ma}, \mathrm{Pr}, \mathrm{Py}$ \\
\hline Physconia enteroxantha (Nyl.) Poelt & $1,2,5,6,9$ & $\mathrm{Ma}, \mathrm{Py}$ \\
\hline Physconia grisea (Lam.) Poelt & 1,9 & Ma, Py \\
\hline Polycauliona candelaria (L.) Frödèn, Arup \& Søchting & 2 & $\mathrm{Ma}, \mathrm{Py}$ \\
\hline Polycauliona polycarpa (Hoffm.) Frödèn, Arup \& Søchting & $1-10$ & $\mathrm{Ce}, \mathrm{Ma}, \mathrm{Pr}, \mathrm{Py}$ \\
\hline Pseudevernia furfuracea (L.) Zopf & 9 & $\mathrm{Ma}$ \\
\hline Ramalina farinacea (L.) Ach. & 8 & $\mathrm{Ma}$ \\
\hline Rinodina pyrina (Ach.) Arnold & 1,2 & $\operatorname{Pr}$ \\
\hline Scoliciosporum chlorococcum (Graeve ex Stenh.) Vězda & $3-6,9$ & $\mathrm{Ce}, \mathrm{Ma}, \mathrm{Pr}, \mathrm{Py}$ \\
\hline Strangospora pinicola (A. Massal.) Körb. & 9 & $\mathrm{Ma}$ \\
\hline Trapeliopsis flexuosa (Fr.) Coppins \& P. James & 10 & $\mathrm{Ma}$ \\
\hline Usnea hirta (L.) Weber ex F.H. Wigg. & 3 & $\mathrm{Ma}$ \\
\hline Xanthoria parietina (L.) Th. Fr. & $1-10$ & $\mathrm{Ce}, \mathrm{Ma}, \mathrm{Pr}, \mathrm{Py}$ \\
\hline
\end{tabular}

Explanations: Ce - Cerasus sp., Ma - Malus sp., Pr - Prunus sp., Py - Pyrus sp. 


\section{DISCUSSION}

The lichen biota of fruit trees (56 species) in selected localities in the Podlaskie Voivodeship is typical and comparable with other areas in Poland. The recorded lichen species are mostly common lichens, found on the bark of trees growing in built-up areas. Heliophilous and nitrophilous species of genus Physcia, Phaeophysia, Polycauliana and Xanthoria are dominant. These lichen species have also been recorded from the bark of fruit trees in other studies dealing with rural areas [Kuziel 1964 a, b, Kiszka, Piórecki 1991, Śliwa 1998, Kościelniak 2004, Szymczyk, Zalewska 2008, Zarabska 2011, Łubek, Biskup 2012, ZarabskaBożejewicz 2016]. The list of species found in this study includes several more interesting taxa, such as Melanelixia subargentifera, Physcia aipolia, Strangospora pinicola.

A similar number of lichen species (53) was recorded in the selected fruit orchards in the Lower Vistula Valley [Lipnicki, Sobieralska 2009]. Among these species are those not found in the Podlaskie Voivodeship, such as Alyxoria varia, Bryoria vrangiana, Physcia dimidiata, Physconia distorta, P. perisidiosa, Tuckermanopsis chlorophylla, Vulpicida pinastri and others.

A large number of lichen species has been found on the bark of fruit trees in the Bieszczady Niskie [Koscielniak 2004] — 105, in Łącka Basin [Kuziel 1964a] - 86, in the Przemyskie Foothills [Kiszka, Piórecki 1991] - 71. Kościelniak [2004] found many rare species of lichens that have not been recorded in the Podlaskie Voivodeship, including, among others, Acrocordia gemmata, Bacidia subincompta, Flavoparmelia caperata, Melanelixia subaurifera, Ochrolechia turneri. Pamelina tiliacea and Punctelia subrudecta.

A smaller number of epiphytic lichen species has been found, among others, 47 species — in the Beskid Sądecki [Śliwa 1998], 40 - in the Przemyskie Foothills within the boundaries of the planned Turnicki National Park [Kiszka, Piórecki 1994], 37 - in the Śnieżnik Massif and Bialskie Mountains [Szczepańska 2008], 32 - in the Wielkopolska Voivodeship, in Tomyśl municipality, in apple orchards [Zarabska et al. 2009], 32 - in the agricultural landscape of Sandr Nowotomyski, in apple orchards [Zarabska 2011], 22 - in Torun [Wilkoń-Michalska et al. 1988], 16 - in Świętokrzyskie National Park [Łubek 2007].

The abundance of epiphytic lichens on the tree bark depends mainly on the bark structure, the nutrient content of the bark and the bark pH [Barkman 1958, Wirth 1995]. Tree bark pH is one of the most important factors affecting the lichen species' distribution [Barkman 1958]. Deciduous trees usually have lower bark acidity than coniferous trees [Barkman 1958], which varies according to the tree species; for example, Picea abies, Pinus sylvestris and Betula pendula have normal acidity ( $\mathrm{pH} \mathrm{3.4-4.0)} \mathrm{and} \mathrm{Acer}$ platanoides, Fraxinus excelsior, Tilia cordata and fruit trees have subneutral $(\mathrm{pH} 4.9-7.5)$ bark in clean-air areas [Wirth 1995].

Differences between the epiphytic lichen biota of trees with similar bark chemistry, were attributable to differences in bark rugosity, dust trapping, microclimate conditions and content of air pollution.

Specific microclimate conditions of phorophytes are thought to promote lichen growth in old orchards. Particularly, lichens are more abundant within and under tree crowns, where there is high air humidity and diffuse solar radiation [Łubek, Biskup 2012]. The diversity of trees and their age within an orchard, types and intensity of human activities in this ecosystem (e.g., agroecosystem, city and village lands) and its surroundings, including levels of air pollution as well as the general environmental conditions affect the epiphytes [Zarabska-Bożejewicz 2016]. Łubek, Biskup [2012] found that the biota of lichens of fruit trees growing in orchards and along roads differed as to the number of species and the degree of coverage. More species diversity was reported in orchards (48 species) than on the bark of fruit trees growing alone or in small groups on the roads (44).

Among the fruit trees under study, the highest number of epiphytic lichens was found on the bark of Malus sp. (52 species). Lichens of this phorophyte in the Podlaskie Voivodeship account for $78 \%$ of the lichen biota of apple trees growing in fruit orchards in Poland [Zarabska et al. 2009, Zarabska 2011, Łubek, Biskup 2012]. In the study area, the following lichens were not recorded on the bark of this phorophyte: Acrocordia gemmata, Alyxoria varia, Bacidia adastra, B. rubella, Candelariella reflexa, Cladonia merochlorophaea, Coenogonium pineti, Flavoplaca citrina, Flavoparmelia caperata, Lecania naegelii, Lecanora piniperda, L. persimilis, Lecidella flavoserediata, Melanelixia glabra, M. subaurifera, Parmelia saxatilis, Parmelina tiliacea, Pertusaria albescens, P. amara, Phaeophyscia chloantha, P. hirsuta, Physconia detersa, P. distorta, P. perisidiosa, Piccolia ochrophora, Placynthiella icmalea, Scoliciosporum sarothamni and Xanthomendoza fallax. The new taxa for this phorophyte in Poland are: Cladonia chlorophaea, Lecanora allophana, $L$. argentata, L. pulicaris, L. varia, Micarea denigrata, Ramalina farinacea and Rinodina pyrina. Apple orchards feature favourable light conditions, difficult access to the water on the trunk and higher $\mathrm{pH}$ of the bark of Malus sp. [Kuziel 1964b], and these allow for establishment and persistence of relatively rich and interesting lichen biota in the nearly deforested countryside [Zarabska et al. 2009, Zarabska-Bożejewicz 2016]. Moreover, favourable conditions for some lichens can be also be created by bark $\mathrm{pH}$ of Malus sp., which is naturally higher in comparison with some other trees, for example, Quercus sp., and can promote occurrence of some specific, group of lichens such as the nitrophytic lichen species [Zarabska et al. 2009]. Orchards are biodiversity hotspots, home to a wide range of organisms including epiphytic lichens. The fruit orchards are considered as important refuges of rare lichen species increasing the biodiversity of the region. Traditional orchards are now included as a priority habitat in the United Kingdom Biodiversity Action Plan [Whitelaw 2012].

\section{CONCLUSIONS}

1. The lichen species diversity of the fruit trees in the study area is comparable with other regions in the country.

2. The lichen species typical for the lichen biota of fruit trees in built-up areas are dominating.

3. The fruit trees growing in orchards are significantly increasing the heterogeneity of the anthropogenic landscape. 


\section{REFERENCES}

BARKMAN J. J. 1958. Phytosociology and Ecology of Cryptogramic Epiphytes. Van Gorcum, Assen.

CIEŚLIŃSKI S., CZYŻEWSKAK., FABISZEWSKI J. 2006. Red list of the lichens in Poland. W: Mirek Z., Zarzycki K., Wojewoda W., Szeląg Z. (red.), Red list of plants and fungi in Poland, s. 71-89. W. Szafer Institute of Botany, Polish Academy of Sciences, Kraków.

FAŁTYNOWICZ W. (ed.) 1994. Porosty Wigierskiego Parku Narodowego. Parki nar. Rez. przyr. 13, 3: 9-28.

FAŁTYNOWICZ W., KOSSOWSKA M. 2016. The lichens of Poland. A fourth checklist. Acta Botanica Silesiaca Monographiae 8, Wrocław.

KISZKA J., PIÓRECKI J.1991. Porosty (Lichenes) Pogórza Przemyskiego. Wyd. Uniw. Warszawskiego, Warszawa.

KISZKA J., PIÓRECKI J. 1994. Waloryzacja przyrodnicza porostów (Lichenes) projektowanego Turnickiego Parku Narodowego. W: Kiszka J., Piórecki J. (red).

Porosty apofityczne jako wynik antropopresji. Materiały z Sympozjum Bolestraszyce, 4-9 września 1993. Arboretum Bolestraszyce 2: 95-122.

KONDRACKI J. 2002. Geografia regionalna Polski. PWN Warszawa.

KOŚCIELNIAK R. 1998. Porosty drzew owocowych w Bieszczadach Niskich. W: Miądlikowska J. (red.), Botanika polska u progu XXI wieku. Materiały konferencji i obrad sekcji 51 Zjazdu PTB, Gdańsk 5-19 września, s. 228. Bogucki Wydawnictwo Naukowe, Poznań.

KOŚCIELNIAK R. 2004. Porosty (Lichenes) Bieszczadów Niskich. Fragm. Flor. Geobot. Polonica, Suppl. 5: 19-78.

KUZIEL S. 1964a. Porosty epifityczne drzew owocowych w Kotlinie Łącka i okolicy. Łódzkie Tow. Nauk., Prace Wydz. III Nauk Mat.-Przyr. 98: 1-42.

KUZIEL S. 1964b. Zespoły porostów epifitycznych na drzewach owocowych w sadach Doliny Dunajca. Acta Agrobot. 16: 5565.

LIPNICKI L., SOBIERALSKA R. 2009. Porosty epifityczne w starych sadach w Dolinie Dolnej Wisły. Parki Nar. Rez. Przyr. 28, 1: 37-49.

ŁUBEK A. 2007. Antropogeniczne przemiany bioty porostów Świętokrzyskiego Parku Narodowego i otuliny. Fragm. Flor. Geobot. Polonica, Suppl. 10: 37-44

ŁUBEK A., BISKUP E. 2012. Porosty epifityczne i grzyby naporostowe drzew owocowych w gminie Sławno (Polska Środkowa). Chrońmy Przyrodę Ojczystą 6, 3: 186-197.
MATWIEJUKA. 2007. Porosty Białegostoku. Analiza florystycznoekologiczna. Tom.1. Wyd. Ekonomia i Środowisko, Białystok.

MATWIEJUKA., KOROBKIEWICZ K. 2012. Stan bioty porostów w miastach Polski. Ochrona Środowiska i Zasobów Naturalnych 51: 85-105.

NOWAK J., TOBOLEWSKI Z. 1975. Porosty polskie. - PWN, Warszawa - Kraków.

ORANGE A., JAMES P.W., WHITE F.J. 2001. Microchemical methods for the identification of lichens. British Lichen Society, London.

PURVIS O., COPPINS B., HAWKSWORTH D., JAMES P., MOORE D. (eds) 1992. The lichen flora of Great Britain and Ireland. The British Lichen Society, London. 710 pp.

Regulation of Minister of Environment, 2014. Rozporządzenie Ministra Środowiska z dnia 9 października 2014 r. w sprawie ochrony gatunkowej grzybów, Dz. U. nr 0, poz. 1408.

SZCZEPAŃSKA K. 2008. Antropogeniczne przemiany bioty porostów Masywu Śnieżka i Gór Bialskich. Acta Bot. Siles. Monogr. 4: 23-36.

SZYMCZYK R., ZALEWSKA A. 2008. Lichens in the rural landscape of the Warmia Plain. Acta Mycol. 43, 2: 215-230.

ŚLIWA 1998. Antropogeniczne przemiany lichenobioty Beskidu Sądeckiego. Instytut Botaniki Uniwersytetu Jagiellońskiego. Prace Bot. 31: 1-158.

WHITELAW M. 2012. Diversity and distribution of epiphytic bryophytes in apple orchards: relationship with tree and substrate variables. http://ethos.bl.uk/OrderDetails. do?uin=uk.bl.ethos.629457

WILKOŃ-MICHALSKA J., GLAZIK N., KALIŃSKA A. 1988. Porosty miasta Torunia. Acta Univ. Nicolai Copernici, Nauki Mat.-Przyr. 63, Biol. 29: 209-253.

WIRTH V. 1980. Flechtenflora. - E. Ulmer Verl., Stuttgart.

WIRTH V. 1995. Die Flechten Baden-Würtembergs. 2 Aufl. -E. Ulmer Verl., Stuttgart.

ZARABSKA D., GUTTOVÁA., CRISTOFOLINI F., GIORDANI P., LACKOVIČOVÁ A. 2009. Epiphytic lichens of apple orchards in Poland, Slovakia and Italy. Acta Mycol. 44, 2: 151-163.

ZARABSKA D. 2011. Porosty w krajobrazie rolniczym Sandru Nowotomyskiego [PhDthesis]. Uniwersytet im. Adama Mickiewicza, Poznań.

ZARABSKA-BOŻEJEWICZ D. 2016. Lichens in the agricultural land of Poland - diversity, threats, and protection: a literature review. Acta Mycol. 51, 1: 1-14. 